\title{
LOVING THE ALIEN. ECOFEMINISM, ANIMALS, AND ANNA MARIA ORTESE'S POETICS OF OTHERNESS ${ }^{1}$
}

\author{
SERENELLA IOVINO \\ Università di Torino
}

Recibido: 04/03/2013

Aceptado: 09/10/2013

\begin{abstract}
In this essay, I analyze how literary imagination can be used as a tool for theoretically exploring the notions of otherness, vulnerability, and human/nonhuman relationships in the framework of feminist ecocriticism. In particular, I examine how a precise literary genre, namely, magical realism, can function as a diffracting lens to make the hybridizations and the overlapping of human, nonhuman, and gendered bodies, visible through narrative strategies that facilitate our affective response. Building my theoretical discourse mostly on feminist animal studies, material ecocriticism, and posthumanism, I consider the work of the Italian writer Anna Maria Ortese (19141998) and her "creaturely poetics of otherness," as exemplified in particular by her novel The Iguana.
\end{abstract}

Key-words: Feminist ecocriticism; Italian Literature; Comparative Literature; Posthumanism; Material ecocriticism; Animals in literature; Magical Realism; Anna Maria Ortese.

\section{Resumen}

En este ensayo, analizo cómo la imaginación literaria puede utilizarse como una herramienta para explorar teóricamente las nociones de alteridad, vulnerabilidad y las relaciones humano/no humano en el marco de la ecocrítica feminista. En concreto,

1. Except for The Iguana (available in English), all the quotes from Anna Maria Ortese's works and from the Italian texts cited in this essay have been translated by me. 
analizo cómo un género literario determinado, a saber, el realismo mágico, puede funcionar como una lente de difracción para hacer visibles las hibridaciones y la superposición de lo humano, no humano y las corporalidades de género, a través de estrategias narrativas que faciliten nuestra respuesta afectiva. Mi discurso teórico se construye sobre todo a partir de los estudios feministas sobre animales, la ecocrítica material, y el posthumanismo, y se centra en el análisis de la obra de la escritora italiana Anna Maria Ortese (1914-1998) y su "poética de criaturas de la alteridad, “ utilizando como ejemplo por su novela La Iguana.

Palabras clave: Ecocrítica feminista; literatura italiana; literatura comparada, posthumanismo; ecocrítica material; animales en literatura; realismo mágico, Anna Maria Ortese. 
This is caught by females bright, And return'd to its own delight. The bleat, the bark, bellow, and roar, Are waves that beat on heaven's shore.

(William Blake)

Believing the strangest things. Loving the alien.

(David Bowie)

\section{Introduction}

Opening her book Creaturely Poetics with a quote from Simone Weil ("the vulnerability of precious things is beautiful, because vulnerability is a mark of existence"), the British interspecies ethicist and literary scholar Anat Pick observes how difficult it is to speak "strictly" about the human or "the animal." It is common wisdom, she notes, that "the distinctions between humans and animals are conceptually and materially indecisive" and "a site of contestation." 3 Still, in the modern age, the "human-animal distinction constitutes an arena in which relations of power operate in their exemplary purity (that is, operate with the fewest of material obstacles)."4

Ever since its appearance, ecofeminism has advocated for the dismantling of the "intersectional oppressions" which encapsulate women, nonhuman animals, "non-normative humans," 6 and whatever subject has been marked as

2. PICK, Anat. Creaturely Poetics: Animality and Vulnerability in Literature and Film, New York, Columbia University Press, 2011, p. 1.

3. Ibid.

4. Ibid.

5. Kemmerer, Lisa (ed.). Sister Species: Women, Animals and Social Justice, Chicago, University of Illinois Press, 2011, p. 6. In Kemmerer's words, "these interlocking oppressions include - to name just a few-speciesism, sexism, racism, and homophobia" (Ibidem).

6. GRUEN, Lori and Kari WeIL. "Animal Others: Editors' Introduction." In Hypatia 27/3 (Summer 2012), pp. 477-487. 479. Gruen and Weil remind that there is "a conceptual link between the 'logic of domination' that operates to reinforce sexism, racism, and heterosexism and the logic that supports the oppression of nonhuman animals and the more than human world more generally, a link that translates into individual

Feminismo/s 22, diciembre 2013, pp. 177-203 
"alien" by dominants systems of power, including the earth. Let us think, for example, of the way feminist thinkers such as Karen Warren, Val Plumwood, Carolyn Merchant, Karen Warren, Carol Adams, Rosemary Radford Ruether, and Greta Gaard, theorize difference in ecological terms. In their view, the category of difference is conceived not simply as a gender issue, but as but as a macro-category that includes and structures many forms of otherness. In the failed acknowledgement of the human-nonhuman interdependency (Plumwood speaks of "denied dependency") an "alienated identity of dominance" is built and "naturalized" by a materially and conceptually oppressive power that "construes and constructs difference in terms of an inferior and alien realm." ${ }^{\prime 7}$ Otherness, in this framework, is associated with vulnerability, and it is patent that both the human and the animal are potentially vulnerable and exposed to forms of oppression. ${ }^{8}$

and institutional practices that are harmful to women, people of color, nonnormative humans, as well as other animals and the planet" (Ibidem)).

7. Plumwood, Val. Feminism and the Mastery of Nature, London, Routledge, 1993, p. 42). From this mechanism, based upon an instrumental exclusion of every form of otherness, Val Plumwood offers an interesting example in her famous "list of dualisms":

$\begin{array}{lll}\text { culture } & \text { / } & \text { nature } \\ \text { reason } & / & \text { nature } \\ \text { male } & / & \text { female } \\ \text { mind } & / & \text { body (nature) } \\ \text { master } & / & \text { slave } \\ \text { reason } & / & \text { matter (physicality) } \\ \text { rationality } & / & \text { animality (nature) } \\ \text { reason } & / & \text { emotion (nature) } \\ \text { mind, spirit } & / & \text { nature } \\ \text { freedom } & / & \text { necessity (nature) } \\ \text { universal } & / & \text { particular } \\ \text { human } & / & \text { nature (nonhuman) } \\ \text { civilised } & / & \text { primitive (nature) } \\ \text { production } & / & \text { reproduction (nature) } \\ \text { public } & / & \text { private } \\ \text { subject } & / & \text { object } \\ \text { self } & / & \text { other }\end{array}$

(Ibid., p. 43). It is clear here that the metanarrative about the supremacy of the "strong pole" (on the left) is associated to a mastery of the "weak pole" (on the right), like the mastery of male over female in the relation we call "gendered."

8. On this topic, see GAARD, Greta. Ecofeminism: Women, Animals, Nature Philadelphia, Temple University Press, 1993; and GAARD, Greta. "Living Interconnections with Animals and Nature." Ecofeminism: Women, Animals, Nature. Ed. Greta C. Gaard. Philadelphia, Temple University Press, 1993. 1-12. GRUEN, Lori. "Dismantling Oppression: An Analysis of the Connection between Women and Animals," Ecofeminism: Women, Animals, Nature. Ed. Greta C. Gaard. Philadelphia, Temple University Press, 1993. 60-90; 
In the recent developments of ecological feminism, these visions have been further articulated, also thanks to the expansion of feminist science studies and the rise of new critical conceptualizations such as posthumanism and the new materialisms, as Serpil Oppermann's essay in this collection vividly shows. ${ }^{9}$ A multitude of relevant theorists both in animal and feminist studies have supported the unsettling of the human/nonhuman ontological divide, and a vast scholarship on zoology, affinity studies, and philosophical ethics (with authors such as Donna Haraway, Matthew Calarco, Cary Wolfe, Giorgio Agamben, Roberto Marchesini, and Jacques Derrida) has addressed this issue in terms which are consistent with ecofeminist visions. Arguing that "We have never been human," Donna Haraway, for example, has convincingly emphasized that "becoming with" the nonhuman is "a practice of becoming worldly." ${ }^{10}$ Human genomes, Haraway reminds us, "can be found in only about 10 percent of all the cells that occupy the mundane space I call my body; the other 90 percent of the cells are filled with the genomes of bacteria, fungi, protists, and such, some of which play in a symphony necessary to my being alive at all." Hence, she concludes, "To be one is always to become with many."11 In a very concrete way, thus, aliens are inside us and enable us to be what we are.

The encounter of ecofeminism with interdisciplinary scientific approaches exhibiting the presence of the "other" in the very core of human materiality has determined, to quote Oppermann, the rise of a "new ecofeminist settlement," one that "opens new eco-vistas into exploring the dynamic co-extensivity and permeability of human and nonhuman bodies and natures." Stressing the material-discursive entanglement of humans and nonhumans in their "differential becoming," 12 this "new ecofeminist settlement" ushers in a vision that Oppermann has provocatively but insightfully defined an "ecology without gender": an ecology that sees human and nonhuman sexed bodies "outside the confines of gendered dichotomies, and thus outside of their abductive

and MerChant, Carolyn. Reinventing Eden: The Fate of Nature in Western Culture. New York \& London, Routledge, 2003.

9. Posthuman and neo-materialist trends in feminist studies are epitomized by the essays and authors featuring in Alaimo, Stacy, and Susan HeKman (eds.). Material Feminisms. Bloomington, Indiana University Press, 2008.

10. HaraWaY, Donna. When Species Meet, Minneapolis, University of Minnesota Press, 2008, p. 3.

11. Ibid., pp. 3-4.

12. The expression is Karen Barad's. See her Meeting the Universe Halfway: Quantum Physics and the Entanglement of Matter and Meaning, Durham \& London. Duke University Press, 2007, p. 149 and passim. 
power." In other words, ecofeminism is not simply a discourse about debunking systems of power, but most of all it is a discourse focusing on the way the category of "difference" is a founding element of the ontological permeability and ethical mutuality between the human and the nonhuman, the "animal": our dialectical "alien" par excellence. It is therefore almost inevitable for feminist thinkers to bring their diverse angles and approaches to the scrutiny of the "myriad of ways" in which "we touch the lives of other animals and ... they touch ours," as Lori Gruen and Kari Weil say in their introduction to the recently published Hypatia Symposium on "Feminists Encountering Animals." 13

The reverberations of this point on ecocriticism are crucial. ${ }^{14}$ Through the understanding of "the linked oppressions of 'nature,' non dominant species, sexualities and genders," 15 and via narratives that appeal to our moral imagination, ecocriticism can shape both a new vocabulary and a new aesthetics for subjugated and vulnerable forms of otherness. Now we can better understand the meaning of Simone Weil's passage on the vulnerability of precious things, quoted in the beginning. As Anat Pick explains, "If fragility and finitude possess a special kind of beauty, this conception of beauty is already inherently ethical." ${ }^{16}$ Such vision implies a recognition of "the other" which explicitly puts into question the human/animal split since, "the relationship between vulnerability, existence, and beauty necessarily applies across the species divide and so delivers us beyond the domain of the human." ${ }^{17}$ This relationship, in other words, entails an ethical and emotional dimension-one that

13. Gruen, Lori and Kari WeIL. "Invited Symposium: Feminists Encountering Animals. Introduction." In Hypatia 27/3 (Summer 2012), pp. 492-493. 492.

14. Greta Gaard, for example, has strongly advocated for the articulation of "an interspecies focus within ecocriticism" that would cross-fertilize ecofeminism and critical approaches apt to "understanding the linked oppressions of 'nature,' non dominant species, sexualities and genders" (GAARD, Greta."New Directions for Ecofeminism: Toward a More Feminist Ecocriticism”. ISLE. 17.4 [Autumn 2010], pp. 643-665.) In general, on feminist ecocriticism, see the ground-breaking works by Patrick MURPHY, Literature, Nature, and the Other: Ecofeminist Critiques. Albany, SUNY Press, 1995; GAARD, Greta and Patrick MuRPHY (eds.). Ecofeminist Literary Criticism: Theory, Interpretation, Pedagogy. Urbana \& Chicago, University of Illinois Press, 1998; and GAARD, Greta, Simon ESTOK, and Serpil OpPERMANN, eds. International Perspectives in Feminist Ecocriticism. London and New York, Routledge, 2013.

15. See GaARD, Greta. "New Directions for Ecofeminism," Op. cit., p. 651. Among these approaches, Gaard lists Simon Estok's notion of ecophobia and Timothy Morton's vision of "ecology without nature."

16. PICK, Anat. Op. cit., p. 3.

17. Ibid., p. 3. 
includes awe (as in the ancient philosophical concept of thaumázein), respect, and love.

In this essay, I will try to analyze how literary imagination can be used as a tool for theoretically exploring these notions. In particular, I will examine how a precise literary genre, namely, magical realism, can function as a lens to make the hybridizations and the overlapping of human, nonhuman, and gendered bodies, visible through narrative strategies that facilitate our affective response toward nonhumans, enabling our perception of them as bearers of a complex otherness which (silently) asks to be included in our ethical horizon.

Considered in this framework, Pick's discourse about vulnerability, uncertain distinctions, and power relations seems to summarize in a remarkable way the creaturely poetics of otherness of the Italian writer Anna Maria Ortese (1914-1998), as exemplified in particular by her novel The Iguana. Analyzing this hybrid female figure, halfway between a reptile and a little girl, and depicted by Ortese as a quasi-human/quasi-animal, namely, a quasi-moral subject in queer and fluctuating forms, I will try to look at the way ecofeminist visions of otherness are delineated in the novel. Here, while the distinctive features of the "alien" become progressively more elusive, a moral bridge between the oppressed human and animal is created in a twofold way: by acknowledging the nonhuman as "exposed" and vulnerable, and by acknowledging the nonhuman other as nestling within the very fragility of the human.

\section{'The tiniest creatures of creation'. Ortese's poetics of otherness}

In his unparalleled book about Ortese's life and works, the biographer Luca Clerici reports the writer's confession about a dream she used to have as a four-years old child:

When I was a child, I had a recurring dream. I was a little girl like there are many - an absolutely ordinary girl; but I used to be attracted by mysterious creatures, by the tiny ones. Once I dreamt about a [little] dragon. It was almost a prediction, an image of how my whole life would be, the symbol of something I would cherish profoundly. When I was young, a dreaming youth, I used to believe that history is made by men and women. What really counts, though, are the children, the small ones, the tiniest creatures of creation. ${ }^{18}$

18. Quoted in CleRICI, Luca. Apparizione e visione. Vita e opere di Anna Maria Ortese, Milan, Mondadori, 2002, p. 42. The dream of the little dragon is also reported in more detailed terms in Ortese's collection of tales In sonno e in veglia, Milan, Adelphi, 1987, pp. 168-169. Here the dragon is described as "A kind of crocodile, with a white chest, his

Feminismo/s 22, diciembre 2013, pp. 177-203 
The "tiniest creatures of creations," whether human or nonhuman, real or fantastic, would be the lasting core of the literary imagination of this autodidact author, a working-class woman from the poor Italian south, now considered to be one of the most prominent Italian writers of the $20^{\text {th }}$ century. "Anti-consumerist, aloof, animalist and ecologist, animated by a non confessional religiosity and by an irrationalist worldview, and politically a libertarian-anarchist," 19 Anna Maria Ortese is author of six novels and of several collections of tales and poems, which, although celebrated by critics, never made her a rich person, or a leading protagonist in the cultural scene of her homeland. Like other female intellectuals who flourished in the second half of the 1900s, she belonged to a generation of women that "had to build their own intellectual presence and their own job as writers in a climate of deep isolation (from men, as well as from other women)." ${ }^{20}$ This makes Ortese's work even more unique in her literary panorama: a complex and problematic figure, she was marginalized from the Italian intellectual sphere because of the often polemical stances she took toward the "cultural industry."

But what makes Anna Maria Ortese particularly inviting for a feminist ecocritical interpretation are the very subjects of her writing: solidarity among living beings (many of her characters are transition-forms or hybrids between the human and the nonhuman), anguish over the human blindness regarding the rights of all vulnerable creatures, a will of redeeming otherness, consideration of nature as a subject and not as an object to possess and to conquer, an insistent interest in landscape and in the world of "the tiniest creatures of creation." Especially in the last years of her life, Ortese's commitment for both Earth and earthlings is charged with passionate polemics against human instrumentalism and all the forms of oppression that come from it. The following quotes are taken from Corpo celeste [Celestial Body] (1997), a short diary to which she entrusted her spiritual legacy, and did it in terms which are amazingly consistent with an ecofeminist vision:

These are the wars lost for mere cupidity: countries with no woods or streams, and cities with no more kids to love or peaceful old people, or women considered above their sheer "use." [...] When peace and right will cease to be only for one part of the living beings, and will cease to mean only the happiness and the right of this privileged part and the pitiless consumption of

red mouth wide open, and with infinitely friendly and meek eyes [...] He resembled a young boy and looked like he knew me" (Ibid., p. 168).

19. CleRICI, Luca. Op. cit., p. 599.

20. ZANCAN, Marina. "La donna." In Letteratura Italiana. Ed. Alberto ASOR ROSA. Turin, Einaudi, 1986. Vol. V, pp. 765-827. 827. 
all the rest, only then-when the peace of the river and bird will be possible, too- the peace and safety of the human will be possible, as easy as a smile. ${ }^{21}$

In a creaturely dimension of innocence-of innocence as the ethical complement of vulnerability-all living things, whether human and nonhuman, were for her entitled to exist and to thrive. Like William Blake, Emily Dickinson, Borges, or Melville, authors who "never cease to tell the unity of the world," 22 and who were her constant inspiration sources, Ortese persistently rejected the idea of an ethical or ontological privilege of the human in a discourse about justice and freedom. ${ }^{23}$ To be fair meant to her to grant freedom to whatever is vulnerable and "precious" - a silence, a garden, a sleeping animal; it meant to let these things be, like in a poem by Jorge Luis Borges ('The just'), which indirectly returns in some of her last pages. ${ }^{24}$ Especially noteworthy are therefore some considerations on freedom and mastery, by her expressed in tones that are at once lyrical and resolute:

Freedom is a breath. All world breathes, not only humans. Plants breathe, and so do animals. [...] Seasons, day, night: they are breath. Tides are breath. Everything breathes and has a right to breathe. [...] It seems to me that a concept of freedom as stealing the other's breath is becoming more and more widespread. Freedom as mastery. [...] To destroy fields and forests, to change and twist the seasons' rhythm; to recklessly keep incarcerating and massacring

21. OrTeSe, Anna Maria. Corpo celeste. Milan, Adelphi, 1997, pp. 52-53.

22. Ibid., p. 123.

23. Besides the mentioned authors, Ortese refers almost exclusively to Anglo-American poets and writers as the roots of her more-than-human "poetic creed." Such figures include Carroll, Coleridge, Keats, Shelley, Defoe, Dickens, Poe, the Brontë family, Austen, Hawthorne, Crane. See ORTESE, Anna Maria. In sonno e in veglia, pp. 176-177; and Corpo celeste, pp. 27, 123, 132, 155 and passim. The idea of a "universal benevolence," such as the one stressed by Mary Wollstonecraft-as shown by Margarita Carretero González's essay in this collection, is also a recurring point in Ortese's poetics.

24. See ORTESE. In sonno e in veglia, Op. Cit., pp. 180-181 (check). Borges' poem reads:

A man who cultivates his garden, as Voltaire wished.

The one who is grateful that music exists.

The one who takes pleasure in tracing an etymology.

Two workmen playing, in a café in the South, a silent game of chess.

The potter, contemplating a color and a form.

A typographer who sets this page well, though it may not please him.

A woman and a man, who read the last tercets of a certain canto.

The one who caresses a sleeping animal.

The one who justifies, or wishes to justify, a wrong done him.

The one who is grateful that there is Stevenson on earth.

The one who prefers others to be right.

These people, who go unnoticed, are saving the world.

(BORGES, Jorge Luis. Selected Poems. Ed. Alexander Coleman. New York, Penguin, 1999, pp. 454-455. The translation has been slightly modified.)

Feminismo/s 22, diciembre 2013, pp. 177-203 
millions of creatures every day, just in order to eat meat, or wear furs; to freely torture every day, in free laboratories, million of beings, as sentient and unknown as humans, to torture them to death ... all this is presented as a defense of the human's own breath, of the human's own freedom! ${ }^{25}$

Reading these lines, it is not surprising that, especially in the last years of her life, Ortese's engagement for the environment and nonhuman animals became increasingly more explicit and firm, up to the point to nominate Greenpeace as the heir of one third of her limited patrimony. But on her moral horizon there was room for all forms of vulnerable otherness: also significant were, in fact, the battles she carried against the death penalty and for the rights of marginalized humans, especially Native Americans. ${ }^{26}$

In spite of her apparent poetic "irrationalism," it would be wrong, though, to read in her position a rejection of culture or of reason tout court. Quite the opposite: reason-a humane reason-is for Ortese our only response to the wildness of human mastery. In that it lifts our understanding up to the nonhuman, reason, she says, "does not subjugate or commodify anything." ${ }^{27}$ Like reason, also culture-an inclusive and compassionate culture, not the equivalent of "cultural industry" - is the territory where the human as human consciously and committedly encounters the nonhuman, building a bond of kinship and care best symbolized, in her eyes, by the image of Saint Jerome removing the thorn from the lion's paw. ${ }^{28}$ In Ortese's works every form of marginalized (and therefore defenseless and vulnerable) otherness is key in a creaturely moral ontology. Seeing existence through this "creaturely prism" assigns culture "to contexts that are not exclusively human, contexts beyond an anthropocentric perspective. It recognizes in culture more than the clichéd expression of the 'human condition' but an expression of something inhuman as well: the permutations of necessity and materiality that condition and shape human life." 29 The liberating function of culture is for her coupled to the acknowledgment of the condition of slavery-of being exposed to an alien will—as shared by human, animals, and the Earth. Ortese has therefore

25. Ibid., pp. 116-117.

26. In her last years, Ortese was also author of many articles on behalf of environmental conservation, both for aesthetic and ethical reasons, and against cruelty toward animals (see e. g. "Poveri animali oltraggiati" ["Poor abused animals"], La Stampa, March 28, 1990, p. 3; "Ortese: chi sono io. Amica, ma delle vittime" ["Who I am. A friend to the victims"], La Stampa, June 19, 1990, p. 17; "Gli animali sono importanti" ["Animals are important"], Lo Straniero, 4, 11-12 (2000), pp. 62-64. See also ClERICI, Luca. Apparizione e vision, Op. cit.

27. ORTESE, Anna Maria. Corpo celeste, Op. cit., p. 103.

28. Ibid., 132.

29. PICK, Anat. Creaturely Poetics, Op. cit., p. 5. 
a clear idea of how interconnected the fate of all living beings is, and of how historical memory needs biological memory to be an effective instrument of such a culture. ${ }^{30}$

This point reinforces and completes the perspective of an ecofeminist reading of her work. In other important passages, she explicitly defines "evil" as the pain we inflict upon the vulnerable others, "upon the other as an animal, as a child, as an old, a stranger, a poor other." ${ }^{11}$ Whether in the flesh of women or animals, the poor or children, or the life of nature itself, Ortese clearly suggests that each is threatened by interlocked systems of oppressions, which subjugate all "nonnormative" beings. Indirectly sharing the conceptual premises of thinkers such as Plumwood or Warren, Ortese conceives her literary profession as a revolution of the moral imagination. Writing signifies to her fighting on behalf of the fragile ones, in that feminist liberation struggle which Oppermann names "ecology without gender." So Ortese:

Let us fight to free the Earth and to include it again in our system of values! Let it come first! Let forests and light, waters and mountains come first! All beings elastic and shining, spiritual and regal that dwell on the Earth: they shall come first. It is man, not the Earth, the one that has to be downsized. And when I say "man," I essentially mean his old culture: an arrogant culture which puts him in the center of every system, as a master and torturer, corruptor and trader of every soul of Life. ${ }^{32}$

It is important to notice that Ortese's vision of the Earth and earthlings as "soul(s) of Life" does not have a strictly confessional background, but emerges from a pantheism rooted in her anarchical literary readings as a self-taught girl. ${ }^{33}$ This "literary pantheism" also explains the stylistic function of magical realism in The Iguana and in many of her other narrative works. Ascribing to (apparently) speechless creatures a power to speak, magical realism is a form of literary pantheism, which sheds light on the inherent vitality, agency,

30. See ORTESE, Anna Maria. Corpo celeste, Op. cit., p. 127.

31. Ibid., p. 129.

32. Ibid., pp. 124-125.

33. A discussion of Ortese's "nature's religion," a mix of more-than-human immanence and creaturely transcendentalism, whose most relevant referent is, in my opinion, the poet William Blake, would be the object of a specific essay. The presence of nature in Anna Maria Ortese's "moral philosophy" is particularly stressed by Monica Farnetti, who sees her "conception of nature intended as a place of exile of painful beings, oppressed by an obscure law which stays at odds with charity and happiness." Farnetti traces Ortese's idea of nature back to writers such as Giacomo Leopardi, Checov, Emerson, Thoreau, Milton and Tennyson, rather than to "professional" philosophers. See FARNETTI, Monica. "Introduzione," in OrTESE, Anna Maria. Romanzi. 2 vols. Ed. Monica Farnetti, Milan, Adelphi, 2005, pp. ix-lxvi. xvii.

Feminismo/s 22, diciembre 2013, pp. 177-203 
and communicative capacity of all beings. Revealing unexpected kinships and existential disclosures, it is the aesthetic code which best fits an extended moral imagination. In Ortese's narrative works, God and angels appear in the forms of butterflies, little ghosts, turtles, invisible birds, or a mysterious puma cub, like in Alonso e i visionari [Alonso and the Visionaries, 1996], her last novel. All of these works, each one of which would certainly deserve a closer analysis, show how literary imagination can be an amazing tool to amplify both the vocabulary of ethics and the ethical insights of feminist and ecological struggles. In Ortese's prose, the "tiniest creatures of creation" are liberated by virtue of a narrative ontology that, lending them word and stories, consigns them to a perfectly horizontal ethical dimension-one which, being contiguous with reality, complements it in the form of vision. In this dimension "creature," to quote Pick again, "is not simply a synonym for the material and corporeal," but rather discloses "a religious vocabulary of creation and created, and so attempts a rapprochement between the material and the sacred." (17). Showing the sacredness (or, if you prefer, the intrinsic value) of all bodily natures, this rapprochement is a step toward a shared, namely, an ecofeminist discourse of liberation. Creating narratives in which the ontological settings are remodeled upon these subversive (more inclusive, and thus more realistic) ethical sights, Ortese shows her faithfulness to a literature that "never cease[s] to tell us the unity of the world." While inviting the readers to abide by humane reason and "believe the strangest things," her magical realist representation of otherness creates the premises for the readers to "love the alien," as Bowie's lyrics (borrowed in the opening epigraph and in the title of this essay) charmingly suggested. Showing reality via the weirdest forms of imagination, magical realism becomes a language that speaks on behalf of the world and its creatures, to whose voice "human" reason is most of the time strangely deaf.

\section{Crossing the Alien. A reading of The Iguana}

The Iguana is the epitome of this ontological narrative strategy. Here imagination is used to reveal the systems that oppress vulnerable creatures, and also to indicate, via the figure of the little Estrellita, all the crossings which are ethically relevant for a posthumanist "relational ontology": in her, human is crossed with nonhuman, oppression is crossed with gender, marginalization is crossed with slavery (and thus with instrumentalism), misery with cruelty, and childhood with powerlessness to articulate a discourse in self-defense. Being all these elements concentrated in and around a hybrid character of girl/reptile (a reptile certainly remindful of the dragon dreamt 
by the four-years-old Ortese) it is evident that, in this novel, the writer did not simply want to extend moral consideration to nonhuman animals, but to explore how the nonhuman is hidden in the human itself. More of less directly, here Ortese seemed as if she wanted to explore the complex "role of animals, animality, and 'the animal' in our fantasies of gender, race, and sex," as insightfully suggested by Kelly Oliver in a discourse about how to combine the perspectives of feminism and animal studies. ${ }^{34}$

First published in 1965, The Iguana has been for decades subject to revisions by its author, and therefore it is not possible to talk properly of a "final version." The text of the critical edition substantially reproduces the first published version of the novel. ${ }^{35}$ My interpretation will be based upon the edition of 1965, which is also the one used for the English translation of the novel. The Iguana's plot is not easy to summarize. Much of the work's difficulty stems not only from complexity of the story itself, but also from the "hispanicity" of Ortese's style, which is visionary and oneiric, in certain points resembling the prose of magical realist South American writers, such as Julio Cortázar, Isabel Allende, or Gabriel García Márquez. ${ }^{36}$ But this visionary world of alien creatures, weird encounters, and unexpected revelations is the very cypher of her creaturely poetics of otherness.

Carlo Ludovico Aleardo di Grees of the Dukes of Estremadura-Aleardi and Count of Milan, familiarly called Daddo, is an architect. He travels across the Mediterranean Sea on a twofold mission: purchasing lands for his rich mother and, on the behalf of a publisher friend of his, searching for "something poetic,

34. In the Hypatia Symposium on "Feminists Encountering Animals," Kelly suggests that, although "associations among objectified others, including women, racialized others, sexual 'minorities,' and animals or animality have become commonplace," scarce theoretical attention has been placed on the complex "role of animals, animality, and 'the animal' in our fantasies of gender, race, and sex" (OLIVER, Kelly. "Ambivalence toward Animals and the Moral Community," Hypatia 27/3 [Summer 2012], pp. 493-498. 496.) I believe that Ortese's novel is a perfect case study for such a critical approach.

35. A philologically commented text of The Iguana can be found in the second volume of ORTESE, Anna Maria. Romanzi. Ed. Monica Farnetti. 2 vols. Milan, Adelphi, 2005. In this volume are also available alternative versions of the novel, which were projected but never published by the writer. Subject to changes in particular is the final part, in which the partial "happy ending" of the 1965 version, is totally overthrown and transformed into a "noir" complete with a closing slaughter perpetrated by the Segovia-Guzman brothers.

36. See BORRI, Giancarlo. Invito alla lettura di Anna Maria Ortese, Milan, Mursia, 1988, p. 77; and Mazzocchi, Giuseppe. "Anna Maria Ortese e l'ispanità." Modern Languages Notes, 112/1 (1997), Italian Issue, pp. 90-104.

Feminismo/s 22, diciembre 2013, pp. 177-203 
[...] a series of cantos, expressing the revolt of the oppressed. ${ }^{137}$ Daddo finds both things in Ocaña, an imaginary Portuguese island. Not much bigger than a rock and almost deserted, Ocaña is as poor and melancholic as its master, don Ilario Segovia-Guzman, a dilettante poet who lives there with his two brothers. In don Ilario's house Daddo unexpectedly encounters a small iguana named Estrellita who works there as a servant, mistreated and despised by the whole family. Don Ilario, once her friend and mentor, is now apparently disgusted with her. He "pays" her with little pebbles taken from the shore, which she carefully keeps in a hidden place. In her state of physical and emotional abandon, sometimes connected to forms of hostility, this surreal Cinderella very soon gains Daddo's sympathy and solidarity. But his solidarity is not limited to the little Iguana. ${ }^{38}$ In fact, seeing the state of profound misery of both Estrellita and her masters-a misery at the same time material and emotional—Daddo desires to help them.

While he is hardly trying to build closer ties of confidence with the Iguana on the one side, and the Segovia-Guzman on the other, the island's immobile situation suddenly changes. One night, a mysterious American heiress arrives in Ocaña as don Ilario's promised bride. While their wedding is being celebrated, the desperate Iguana throws herself into a well. Daddo saves her, but loses his life as a result. Before dying, he has a deeply symbolic vision: embodied in a dead white butterfly, Daddo sees God and recognizes it as an immensely vulnerable little creature. At this point, in a state suspended between hallucination and cognitive insight, he understands Estrellita's "truth": "the Iguana is not an Iguana, but a poor servant, a little girl reduced by misery, passions, and ignorance to a quasi-animal condition." ${ }^{39}$ While he passes on, Daddo feels "that [...] iguanas are warnings. That there are no iguanas, but only disguises thought up by human beings for the oppression of their neighbors and then held in place by a cruel and terrifying society." 40

The Iguana is a complex work in which the allegorical and poetic motives are interlaced with ethical, social, and historical ones. In the otherness of this reptile-girl, Ortese elicits all the constructs of mastery associated by ecofeminism with the notion of oppressed subjects: she is a woman, an animal, a servant; she lives in a world split into colonized and colonizers; her language

37. Ortese, Anna Maria. The Iguana. Tr. Henry Martin. Kingston and New York, Mc Pherson \& Company, 1986, p. 4.

38. "Iguana," when referred to Estrellita, is always capitalized by Ortese.

39. ORTESE, Anna Maria. "Appendice II. La bestiuccia." In Romanzi. Ed. Monica Farnetti. 2 vols. Milan: Adelphi, 2005. Vol. I, pp. 967-971.970.

40. ORTESE, Anna Maria. The Iguana, Op. cit., p. 180. 
is primitive, her behavior passionate and irrational. Moreover, she cannot even count on the consolation of an afterlife redemption: as her masters made her believe, she has no soul, and her life is sheer and mechanical materiality. But, in spite of her complete subjugation, her figure and her presence are dialectically determining in order for her masters to exist as masters. In a world dominated by men and by a spirit of conquest and "hyperseparation," Estrellita is a figure of vulnerable otherness and a warning: she warns about the "denied dependency" of the world of her oppressors on her own world and on her own existence.

In this context, Ortese's attacks toward the established social hierarchies start with an attack to their underlying cultural vision. Even though it is claimed to be a rehabilitation of the "oppressed" (as in Daddo's "editorial" research and poetical "discoveries") in the end this kind of "culture" acts as an extension of the logics of capitalism, turning out to be part of a discourse which reinscribes the "oppressed" as such. This becomes clear from the opening lines of the novel. Here a peculiar combination of materialist concerns and bourgeois culture (epitomized by the Milanese well-off society) transforms nature in a twisted image, midway between utopia and economic good. Building an unexpected alliance with the Reader (here, a capitalized noun), addressed by Ortese always in the second-person singular pronoun, the narrator's point of view and implicit irony become patent:

Surely, Reader, you have heard about the springtime travels of the Milanese, on the lookout all around the world for real estate, buying up tracts of land for the construction of villas and hotels, naturally enough, and maybe with working class dwellings to come a little later. But most of all, they hunt for still intact expressions of what they understand as "nature," believing in a mixture of freedom and passion, with not a little sensuality and a shade of folly, for which the rigors of modern life in Milan seem to make them thirst. ${ }^{41}$

According to Ortese (and here we can recognize the influence of Marxism on her thought), culture, when it is an expression of the dominating classes, is never guiltless, not even when it claims to be on the side of the dominated classes. Feelings of social resistance cannot be expressed or searched for, she writes, "forgetting that not even feelings survive-neither feelings nor any desire to express them-when people have no money (given the world's time-honored conventions), or where money can buy everything, or where penury cohabits with great ignorance." ${ }^{42}$ In fact, "the oppressed don't even

41. Ibid., p. 1.

42. Ibid., p. 4.

Feminismo/s 22, diciembre 2013, pp. 177-203 
exist, or can't, at least, have any awareness of being oppressed when their condition is authentic and a legacy from a distant past." ${ }^{43}$

Because of these opening premises, the novel is thus an attempt to criticize and to subvert the system of mastery implied in this kind of culture, a culture which, as she will repeatedly say in Celestial Body and in her other non-fiction writings, is "old" and amnesiac. In The Iguana, the "traditional" rationality of this oppressive world is overthrown both by the character of Estrellita, herself an alien, an indefinite "other-than-human," and by Daddo, who constitutes a breakdown in the chain of the oppressors. With their unexpected proximity, the little Iguana and Daddo represent the "side possibilities" which only can crack and dismantle the "oppositive and hierarchical epistemology" inbuilt in the "bottlenecks of patriarchal logic." ${ }^{44}$ For this reason the moral background of the novel is an invitation to quit the reassuring framework of dominant categories (whether social, cultural or existential). It is an invitation to see past a privileged status and to move toward an ethic of proximity, an ethics without limits, in which there are not "liminal moral subjects" but full-fledged ethical presences, however alien and surprising they might seem. ${ }^{45}$ This becomes clear in Daddo's encounter with the iguana:

Daddo's surprise was tremendous. He had taken her for a shrunken old woman, but in front of him was a bright green little beast, about the height of a child-an enormous lizard from the look of her, but dressed in woman's clothes with a dark little skirt, a white corset, old and shabby, and a multicolored apron clearly patchworked from the family's stock of rags. To hide her ingenuous little snout, which was a sort of whitish green, she wore yet another dark cloth on her head. She was barefoot. [...]

The creature he had addressed as "little grandmother" was not even a full-grown girl! She was still a child iguana no more than seven or eight years old who looked aged and dry only because of the typically wrinkled features of her species and a general decline, caused no doubt by carrying weights, constant serving, and who knows what a state of savage loneliness too much for any youthful creature, even a beast. ${ }^{46}$

43. Ibid., p. 4.

44. As Cristina Della Coletta wrote in her essay on Ortese and the idea of utopia, "the contact with these side-possibilities which come out from the cracks and fractures of thinking, and are based upon the refusal of an oppositive and hierarchical epistemology, constitutes one of the most powerful ways out from the bottlenecks of patriarchal logic" (Della Coletta, Cristina. "Scrittura come utopia: La lente scura di Anna Maria Ortese." Italica 76/3 [1999]: 371-88. 380)

45. "Liminal moral subjects" is an expression used by Oliver, Kelly. "Ambivalence toward Animals and the Moral Community," Op. cit., p. 495.

46. ORTESE, Anna Maria. The Iguana, Op. cit., pp. 17-19. 
The way Ortese represents this encounter is significant. The strategic use of the magical-realist style is instrumental for a realigning of the ethical priorities in Daddo's perception. Compared to Estrellita's appalling misery (first ethical close-up of the scene), her strange appearance soon becomes a minor detail. The alien character can therefore be translated into the moral vocabulary of a language of kinship ("a child iguana," my emphasis), while bewilderment is superseded by feelings of spontaneous closeness and of condemnation of her sufferings ("who knows what a state of savage loneliness too much for any youthful creature, even a beast"). Neither completely a reptile nor a woman, Estrellita is evidently a moral and ontological hybrid. Nonetheless, Daddo's compassion and increasing tenderness (here denoted by the terms "little grandmother," "little beast," "child" and by the descriptive function of diminutive forms of nouns) soon become the leading chords in his encounter with such an apparently odd creature. Masterfully using a rhetorical strategy that makes appear emotionally normal what is logically absurd, Ortese characterizes Daddo as disconcerted not much by Estrellita's appearance, but rather by her fragility and pain, also expressed by the way her clothes and figure are represented. In this respect, the phrase "She was barefoot" nearly creates in the reader a synesthetic feeling of exposure, surprise, intimacy, and discomfort.

In removing Estrellita's constructed "truth," the non-human body of the Iguana acts both as a symbol and as a disguise. In doing this, Ortese stressed the irreducibleness of the "other," its being a stranger-also by means of its body-in a world ruled by "sameness." And it is not incidental that in the novel Estrellita is the only meaningful female figure in a men's world. Her body is at the same time always an animal body and always a gendered body. As such, the body itself can be interpreted as a vehicle of otherness. In Estrellita, the "body as other" is projected on the non-human as absolute otherness, but also as the sign of a fracture with the principle of "sameness" and its structure of domination. ${ }^{47}$

As if Ortese prefigured them some thirty years in advance, in Estrellita's marginalization we can recognize the features of Val Plumwood's famous "list of dualisms." ${ }^{48}$ We find here the dualism between male and female, human

47. On gendered body as essential to the definition of individual identity and on its being a medium in the relationship between the "other" and the "same," see IRIGARAY, Luce. I Love to You: Sketch of a Possible Felicity in History. London, Routledge, 1996, pp. 61-62; and IRIGARAY, Luce. An Ethics of Sexual Difference. Tr. Carolyn Burke and Gillian C. Gill. Ithaca, New York, Cornell University Press, 1993, pp. 95-113.

48. See above in this essay, note 7.

Feminismo/s 22, diciembre 2013, pp. 177-203 
and nonhuman, master and slave; but also the dualism between public and private (where the sphere of private is that of the iguana's semi-reclusion, relegated to live in a dark cubbyhole under the kitchen's stairs and forced to behave as if she were invisible); between subject and object (her identity is a sheer function of her utility); rationality and animality (her masters speak "of animality as necessarily distinguished by its lack of that highest good called the Soul"49); universality and singularity (a weird individual, Estrellita is theoretically as well as morally anti-taxonomical, and there are no universal categories in which she could be understood, "assumed" and "redeemed" from her ontological solitude); of civilized and primitive and of culture and nature (Estrellita is illiterate and her language is extremely poor, especially compared to her master's poetic aspirations); of freedom and necessity (after having been repudiated, Estrellita becomes an "animated instrument," almost a mere mechanism).

Among these patterns of mastery, social oppression plays a fundamental role. As Italian critic Giancarlo Borri writes, Estrellita "is the example [...] of a creature taken as an 'economic good', solely considered [...] for its content of utility." ${ }^{50}$ The core of such oppression lies in its asymmetric bilaterality: this mechanism in fact "requires the creature itself to be fully aware of-and basically to accept-such a low." ${ }^{51}$ That is to say, the experience of oppression is so deeply rooted and internalized to be the only means by which oppressed subjects can form their vulnerable identities. Pebbles are an example: Estrellita accepts and keeps them jealously, even though she knows very well that they do not have any real value. Those pebbles are, in fact, the only means through which she can have an idea of herself, and make herself acknowledged and accepted, although as an "inferior being." This suggests that "in the obscure and unfathomable extraneousness of the universe, conscious life can survive and sustain itself only through the degrading mediations of utility." ${ }^{152}$ The passage, "there are no iguanas, but only disguises thought up by human beings for the oppression of their neighbors and then held in place by a cruel and terrifying society," 53 perfectly expresses the gist of the story. In a world of oppressors the "other," however "similar," is oppressed by definition. In this world, this oppressed is an animal, a woman, a poor, and a child. She is,

49. ORTESE, Anna Maria. The Iguana, Op. cit., p. 96.

50. BORRI, Giancarlo. Invito alla lettura di Anna Maria Ortese, Op. cit., p. 58.

51. Ibid., p. 58.

52. Ibid., p. 58.

53. ORTESE, Anna Maria. The Iguana, Op. cit., p. 178.

Feminismo/s 22, diciembre 2013, pp. 177-203 
in other words, one among the innumerable "tiniest creatures of creation," a vulnerable alien.

This creaturely dimension is reinforced when Ortese introduces other kinds of dualisms, seemingly neglected by Plumwood's list, but crucial in the writer's poetics of otherness: the ethical-eschatological dualisms of good and evil, and of salvation and damnation. For Ortese, spirituality functions at a basic level in the process of subjugation. Taking advantage of Estrellita's ignorance and naiveté, her masters induced her to believe not only that she does not have a soul, but even that she herself is a creature of evil. This constructed arrangement determines for Estrellita an "inconfrontable terror of herself." Ortese notes that her mind is as simple as the mind of all the "subalternsespecially children and animals, who are defenseless creatures of weakness entirely without resources." 55

In order to emphasize Estrellita's feeling of spiritual loneliness-a loneliness, which involves abyssal marginalization and abandon-Ortese once again addresses "you," the Reader:

But have you ever given a thought to the desperate plight of Perversity or Wickedness itself, deprived for virtually mathematical reasons of all possible struggle with itself, or of flight from itself, and therefore condemned to the constant horror of its own desperate presence, this presence being nothing other than itself? No, that's something you have never thought about. ${ }^{56}$

Like in the dream of the little dragon, compassion for the alien is a keyword here. This is, in Simone Weil's words, "compassion for every creature, because it is far from the Good. Infinitely far. Abandoned. God abandons our entire being-flesh, blood, sensibility, intelligence, love-to the pitiless necessity of matter." ${ }^{57}$ The logic of dehumanization - and in this case, the identification of a human with a reptile, a snake-like creature, in all its overtly evident symbolical layers-works at the deepest levels of consciousness, creating not only an alienated identity, but also depriving this identity of any further projection in space and in time. Above all Estrellita's spiritual subjection consists not only of her being condemned to embody evil itself, and of her being without soul; it also consists most of all in her being deprived of every right to have a feeling of hope. She is banned from any chance of salvation. Heaven, in whatever form, is denied to her through systematized oppression:

54. Ibid., p. 92.

55. Ibid., p. 57.

56. Ibid., p. 93.

57. WeIL, Simone. "Epilogue." In Springsted, Eric O. (ed.). Simone Weil, New York: Orbis, 1998, pp. 142-143. 142. 
— "Do I have to go to hell?"

— "What did you say?" [Daddo] hadn't understood.

— "I said, do I have to go to hell, I mean when I die, o senhor?"

— "Neither to hell nor to heaven," replied [Daddo], suddenly cool [...], "if you don't have a soul."

Another silence, with the Iguana slightly turning her neck, wary of a returning pain.

- "The Marquis," she continued, her voice so thin as to seem to have fissured ... "is going to heaven today, right after lunch. He's going on the boat; and after all the water, there's the sky and the Holy Virgin, and all the constellations. But I can't go there. The Virgin won't allow it." [...]

[Daddo] felt that the whole world of Christianity had cracked in two and was precipitating into the abyss. His pain was enormous and he asked, "Who... told you that?"

Here again, the creature, slightly stretched her neck, wanting to focus it as the site of all her hurts. [...]

— "Who told you that, little Iguana?"

Her only reply was the sweet, stupid stare of a creature resigned to the uselessness of formulating further noises or bothering to babble them out. ${ }^{58}$

Insisting on her absolute exclusion, this passage sheds light on the ideological violence engrained in Estrellita's subjugation-one based on the fact that animals "have traditionally been perceived as pure necessity, material bodies pitted against human mindfulness and soulfulness." 59 Additionally, though, the exchange points to another interesting element of Ortese's creaturely poetics of otherness. In fact, the process of dehumanization and alienation discloses not only a domineering intention, but also a profound inability to understand both the "other" and the "same," the oppressed as well as the oppressor. ${ }^{60}$ Alienation, in other words, is not limited to the weaker pole of the dualism. This appears clearly in the way Ortese characterizes the Segovia-Guzman, Estrellita's masters. Their endless misery, verging on madness (in don Ilario) and stupidity (in his brothers), shows how they are themselves alienated subjects. To an external and benevolent eye such as Daddo's, Don Ilario and his brothers are victims (surely not guiltless) of a loss, of a "failed experience of the other," as Luce Irigaray would say. In them a "failed experience" consists in denying the mutual belonging of different forms of being, both social and natural. In their ignorance, the life of the Segovia-Guzman brothers is rooted

58. ORTESE, Anna Maria. The Iguana, Op. cit., pp. 154-155.

59. PICK, Anat. Op. cit., p. 4.

60. To quote biologist Steve Olson: "Denying the humanity of other people has always been a way to justify oppressing and exterminating them, and science has a long, sad history of contributing to theses atrocities" (OlSON, Steve. Mapping Human History: Discovering the Past Through Our Genes. New York: Houghton Mifflin, 2002, p. 13). 
in separation. Unlike Daddo, they will not be able to understand that "among the various species" an "affectionate collaboration and a common effort to rise above the terrestrial" may exist. ${ }^{61}$ The undefined time in which don Ilario used to love the Iguana symbolizes, therefore, a past immemorial when there was a form of friendship between human beings and the Earth, a friendship now lost-and with that loss also the oppressors' decline. And though their decline may be more silent, it is no less tenacious.

With its atypical ideological background (a Marxism neither revolutionary nor teleologically utopian, accompanied by a sort of "Christian animism"), The Iguana is a ballad for the redemption of the oppressed; quite paradoxically, however, this redemption reverberates on the oppressors, too. In this context Daddo plays a fundamental role. Daddo tries to redeem the oppressors' "class," to which he belongs by birth, becoming himself a mediator between the two poles of the dualism. But, at the end, his attempt of redemption is unsuccessful. With his death, in fact, he completely quits the oppressors' "terrifying society": "He himself had been product and expression of such a society, but now he was stepping out of it. This made him content." 62 Care is the leitmotiv of this discourse. By caring for the little Iguana, Daddo's interest in her-an interest, which is nonetheless implicitly erotic-is justified and sublimated. Daddo's way of relating to Estrellita reveals a form of love that "lets [her] be." This "letting one be" is comparable to what philosophers Emmanuel Lévinas and Luce Irigaray had in mind when they spoke about "caressing," a form of "caring" for another-a form which is also essentially a "becoming place" to another, "receiving" another, making room in order to allow one to have their being according to their nature and potentialities ${ }^{63} \mathrm{To}$ paraphrase Borges, the one who "caresses a sleeping animal" and lets her be among all the precious and vulnerable forms of existence, will save the world.

In Daddo, the "love for the alien" includes a vast range of aspects that, passing through a sublimated eros and a maternal-paternal care, culminate in a general process of (ethical and metaphysical) acknowledgement and (cognitive) understanding. In his desire to be at the same time Estrellita's spouse, father, and mother, in order to offer her freedom and protection (he dreams about taking her to Milan, and giving her a proper childhood and education, and eventually even to marry her), Daddo starts a process of inclusion and

61. ORTESE, Anna Maria. The Iguana, Op. cit., p. 97.

62. Ibid., p. 180.

63. See IrIGARAY, Luce. An Ethics of Sexual Difference, Op. cit., pp. 183-91. For a phenomenological interpretation of caressing, see LÉVINAS, Emmanuel. Totality and Infinity: An Essay on Exteriority. Tr. Alphonso Lingis. Dordrecht, Kluwer, 1980, pp. 257-59. 
identity clarification that involves not only the Iguana, but the fundamental order of things. ${ }^{64}$ Although in terms of visions and hallucinations, he understands what the mechanisms of oppression are and the fragility of oppressed creatures.

His feverish vision of God in the form of a dying white butterfly (in Italian, a female figure) validates and complements this insight. Here Ortese seems to suggest that the constructs of oppression involve also the dualism of humanity (as the stronger pole) and God (as the weaker pole). In so doing, she can be put in a common conceptual horizon with Dostoevskjis The Great Inquisitor and philosopher Hans Jonas' The Concept of God after Auschwitz, two masterful expressions of God's impotence in front of human constructs of oppression and power. In her novel, Ortese reports Daddo's vision by directly involving the Reader in the conversation:

Surely you've longed to know the true semblance of this Being whom the centuries have surrounded with fables while leaving us always uncertain of having been faced with the undeniable. What lay there, curled up on a leaf and asleep, was a simple white butterfly.

But what a grace it must have had as it hovered over meadows and flowering shrubs before the tremendous event of its death! A simple weak grub, but with the purest wings-wings still trembling (perhaps fluttering with the breathing of the persons in the hall) in an appearance of life. Golden antennae, and minuscule eyes overflowing with goodness, very pure and very sad.

Wondering that so weak and simple a creature, now robbed of life, could contain the secret, the very origins of the immense astounding universe with all its splendors, gifts, and everything that he and other nobles had possessed and enjoyed, the Count became aware of just how unpardonable that murder would always remain, and that the grief of the Constellations was infinite. ${ }^{65}$

64. It would be highly interesting, here, to apply Julia Kristeva's extension of Freudian analysis in her notion of "abjection" and in her theorization of "displacement"-a perceptional dynamics meant to cover "the truth of the intolerable" by way of creating a projectual identity in which the animal acts as a substitute of the human (KRISTEVA, Julia. The Powers of Horror: An Essay on Abjection. Tr. Leon S. Roudiez, New York, Columbia University Press, 1982, p. 129). Abjection, according to Kristeva, is fear of something that we don't clearly know or cannot neatly define. Following Freud, she explains the process of abjection as a projection onto the external world of some internal ambivalence and bewilderment we experience. Kristeva maintains that, in order to recognize ourselves as "clean and proper" human beings, we enact a process of "abjection," through which we separate ourselves from nonhuman animals and project whatever is beastly in ourselves onto animals. I believe that Daddo's missed identification of Estrellita with a human being is clearly inscribed in this dynamics: due to the "intolerable truth" of her oppression (Estrellita is actually dehumanized by her "beastly" masters), Daddo displaces her specific identity onto a nonhuman animal.

65. ORTESE, Anna Maria. The Iguana, Op. cit., pp. 174-175. 
The choice of representing God as a butterfly in a novel based on the "moral metamorphosis" of a reptile might not be incidental. It is interesting to remember that butterflies (and snakes, taxonomically related to iguanas) were considered as symbols of metamorphosis during the Neolithic age. As such they embodied the "transformative power" of the ancient Goddess, worshipped in matriarchal Crete. In her famous essay The Chalice and the Blade, Riane Eisler, for instance, mentioned a "seal impression from Zakro, eastern Crete, portraying the Goddess with the wings of an eyed butterfly. Even the later Cretan double axe [...] was a stylization of the butterfly." 66 But the butterfly form is also remindful, here, of the quintessential fragility and innocence of God's creatures, as splendidly portrayed in William Blake's Auguries of Innocence ("Kill not the moth nor butterfly, / For the last judgment draweth nigh.").

Embodying the coincidence between a transcendent principle, a vulnerable creature, and a nonhuman being, the butterfly-shaped "creaturely" God fashions in The Iguana another valence in which otherness and innocence are superimposable concepts, thus resonating with Blake's poem. In an etymological sense, "innocent" means something which is "not noxious." This implies necessarily the existence of an otherness, as well as its acknowledgement. Being non-noxious, in fact, requires that, besides me, there are in the world other forms of existence to which my presence is potentially harmful. Innocent, therefore, is the one who abstains from being harmful to other beingsthe one who lets the other be, caressing them, listening to their (silent) calls. So conceived, innocence means a shared form of being in the world. It is an act of love. Such innocence is here personified not only by the God/butterfly, but also by Daddo himself. By acknowledging otherness and letting it be as an essential part of the world, he consciously acts as an "innocent"-a harm-less creature. In so doing, he rejects the system of oppression, which is at odds with a shared form of being in the world. If we interpret this episode in the light of the closing lines of Blake's Auguries of Innocence, another element emerges. After enumerating a series of intersections between creaturely vulnerability and the divine in forms of animals and "oppressed" others, Blake in fact concludes:

66. EISLER, Riane. The Chalice \& the Blade: Our History, Our Future. San Francisco: Harper, 1988, p. 18. It is also important to stress that oppressed creatures are, here as well as in other works by Ortese, always the symbol of a transcendental reality. See for example her last two novels Alonso e i visionari ([Alonso and the visionaries]) and The Lament of the Linnet. 
God appears, and God is light,

To those poor souls who dwell in night;

But does a human form display

To those who dwell in realms of day.

With metaphysical irony, the poet suggests that God fully appears only to the oppressed ones-the "poor souls" that do not possess the "light" of human reason: the "tiniest creatures of creation," as Ortese would name them. On the opposite side, only "those who dwell in realms of day," namely, humans, see God in a "human form," hence limiting it. Choosing the side of innocence, and thus becoming an alien himself, Daddo no longer needs human codes to see God. Like "those poor souls who dwell in night," he can see the both the human in a little Iguana and the divine in the luminous innocence of a dead white butterfly.

\section{Conclusions. A generous ethics and the truth of non-reality}

Reflecting on "her" authors in a book of 1987, In sonno e in veglia [In sleep and wake], Ortese writes: "Nobody has discovered and sung the World, like the British and the Americans once did. Even while narrating, they sung the World's marvelous Non reality-a Non reality which is the Truth." ${ }^{67}$

Literature, like art in general, has the power to reveal the "truth" of the world, Hegel maintained. There are few literary genres that are as able to extend reality while they extend moral imagination as magical realism does. Seeing "the unity of world" in the most unpredictable forms, authors such as Wollstonecraft, Borges, Blake, Austen, and Ortese create in their works figures that, acting as "catalyzers" of ideas and emotions, proceed to unexpectedly enlarge the boundaries of ethics and ontology. In so doing, they not only reveal the world but re-enchant it. Telling stories of crossings and metamorphoses, the marvelous creatures emerging from their imagination are, as Jane Bennett writes, "like strange attractors, then each is always in a state of becoming; each is not simply a species crossing but a crossing species." ${ }^{\circ 8}$ A crossing (and most of all, literary crossings of imagination and reality) is, in other words, able to "bring new things into being," cultivating "ethical sensibility," and generating "what might be called a presumptive generosity toward the animals, vegetables, and minerals within one's field of encounter." ${ }^{\prime 9}$

67. ORTESE, Anna Maria. In sonno e in veglia, Op. cit., p. 177.

68. Bennett, Jane. The Enchantment of Modern Life: Attachments, Crossings, and Ethics. Princeton and Oxford, Princeton University Press, 2001, p. 17.

69. See Ibid., pp. 30-31. 
The feminist framing of animal studies is also a chapter of this generous ethics. Its integral "creaturely poetics" conveys a re-enchantment made of crossings, of rediscovered proximities, of cognitive expansions. Taking us from a species-specific moral approach to an interspecies ethics of bodily-affective connections, this vision displaces the ethical emphasis from "the same" to "the other," whereby otherness is put in the mangle, and encounters of different co-existing beings, included ourselves, are created. Here the other is neither neutralized nor distanced, but rather acknowledged as a fundamental element of our own becoming. The other-and we are ourselves others-is already always with its own other, dialectically entangled in bodily and emotional relationships with it.

Whether through figures of women, nonhumans, children, dragons, lizards, butterflies, and every other vulnerable creature, a conceptual horizon is here open, which invites us to see the "same" as complemented by the "other" not by way of mirroring, but rather by way of diffraction: an encounter in which differences at the same time coalesce and matter. ${ }^{70}$ Permeability, and not only vulnerability, is the mark of existence. The unity of the world is made by its innumerable stories and crossings.

\section{Bibliographic References}

Alaimo, Stacy, and Susan HeKMAN (eds.). Material Feminisms. Bloomington, Indiana University Press, 2008.

BARAD, Karen. Meeting the Universe Halfway: Quantum Physics and the Entanglement of Matter and Meaning, Durham \& London, Duke University Press, 2007.

BennetT, Jane. The Enchantment of Modern Life: Attachments, Crossings, and Ethics. Princeton and Oxford, Princeton University Press, 2001.

BORGES, Jorge Luis. Selected Poems. Ed. Alexander Coleman. New York, Penguin, 1999.

BORRI, Giancarlo. Invito alla lettura di Anna Maria Ortese, Milan, Mursia, 1988

CleriCI, Luca. Apparizione e visione. Vita e opere di Anna Maria Ortese, Milan, Mondadori, 2002.

Della Coletta, Cristina. "Scrittura come utopia: La lente scura di Anna Maria Ortese." Italica 76/3 (1999): 371-88.

EISLER, Riane. The Chalice \& the Blade: Our History, Our Future. San Francisco: Harper, 1988.

FARNETTI, Monica. "Introduzione." In ORTESE, Anna Maria. Romanzi. 2 vols. Ed. Monica Farnetti, Milan, Adelphi, 2005, pp. ix-lxvi.

70. On diffraction, see BARAD, Karen. Meeting the Universe Halfway, passim. 
GAARD, Greta. "Living Interconnections with Animals and Nature." Ecofeminism: Women, Animals, Nature. Ed. Greta C. Gaard. Philadelphia, Temple University Press, 1993. 1-12.

- Ecofeminism: Women, Animals, Nature Philadelphia, Temple University Press, 1993

— "New Directions for Ecofeminism: Toward a More Feminist Ecocriticism". ISLE. 17.4 (Autumn 2010), pp. 643-665.

GAARD, Greta, Simon ESTOK, and Serpil OpPERMANN (eds.). International Perspectives in Feminist Ecocriticism. London and New York, Routledge, 2013.

GAARD, Greta and Patrick MurPhy (eds.). Ecofeminist Literary Criticism: Theory, Interpretation, Pedagogy. Urbana \& Chicago, University of Illinois Press, 1998.

GRUEN, Lori. "Dismantling Oppression: An Analysis of the Connection between Women and Animals." In Ecofeminism: Women, Animals, Nature. Ed. Greta C. Gaard. Philadelphia, Temple University Press, 1993. 60-90.

GrUEN, Lori and Kari WeIL. "Animal Others: Editors' Introduction." Hypatia 27/3 (Summer 2012), pp. 477-487.

— "Invited Symposium: Feminists Encountering Animals. Introduction." Hypatia 27/3 (Summer 2012), pp. 492-493.

HaraWAY, Donna. When Species Meet, Minneapolis, University of Minnesota Press, 2008.

IrIgARAY, Luce. An Ethics of Sexual Difference. Tr. Carolyn Burke and Gillian C. Gill. Ithaca, New York, Cornell University Press, 1993.

- I Love to You: Sketch of a Possible Felicity in History. London, Routledge, 1996.

Kemmerer, Lisa (ed.). Sister Species: Women, Animals and Social Justice, Chicago, University of Illinois Press, 2011.

KRISTEVA, Julia. The Powers of Horror: An Essay on Abjection. Tr. Leon S. Roudiez, New York, Columbia University Press, 1982.

LÉVINAS, Emmanuel. Totality and Infinity: An Essay on Exteriority. Tr. Alphonso Lingis. Dordrecht, Kluwer, 1980.

Mazzocchi, Giuseppe. "Anna Maria Ortese e l'ispanità." Modern Languages Notes, 112/1 (1997), Italian Issue, pp. 90-104.

Merchant, Carolyn. Reinventing Eden: The Fate of Nature in Western Culture. New York \& London, Routledge, 2003.

MurPhy, Patrick. Literature, Nature, and Other: Ecofeminist Critiques. Albany, SUNY Press, 1995.

Oliver, Kelly. "Ambivalence toward Animals and the Moral Community." Hypatia 27/3 (Summer 2012), pp. 493-498.

Olson, Steve. Mapping Human History: Discovering the Past Through Our Genes. New York: Houghton Mifflin, 2002.

ORTESE, Anna Maria. "Appendice II. La bestiuccia." In Romanzi. Ed. Monica Farnetti. 2 vols. Milan: Adelphi, 2005. Vol. I, pp. 967-971. 
- Corpo celeste. Milan, Adelphi, 1997.

- In sonno e in veglia, Milan, Adelphi, 1987.

- Romanzi. Ed. Monica Farnetti. 2 vols. Milan, Adelphi, 2005.

- The Iguana. Tr. Henry Martin. Kingston, New York: Mc Pherson \& Company, 1986.

PICK, Anat. Creaturely Poetics: Animality and Vulnerability in Literature and Film, New York, Columbia University Press, 2011.

Plumwood, Val. Feminism and the Mastery of Nature, London, Routledge, 1993.

WeIL, Simone. "Epilogue." In SpringSted, Eric O. (ed.). Simone Weil, New York, Orbis, 1998, pp. 142-143.

ZANCAN, Marina. "La donna." In Letteratura Italiana. Ed. Alberto Asor RosA. Turin, Einaudi, 1986. Vol. V, pp. 765-827. 